\title{
A Feminist Stylistic Analysis of Doris Lessing's The Fifth Child (1988)
}

\author{
Zahra Rahimnouri \& Azra Ghandehariun \\ Zahra.rahimnouri1994@gmail.com,azraghandeharion@gmail.com \\ Department of English Literature and Language, Ferdowsi University of Mashhad, Iran
}

\begin{abstract}
This study is a feminist stylistic analysis of The Fifth Child (1988). This study attempts to combine literary and linguistic theories by using the feminist stylistic
approach of feminist stylisticians. This study investigates the lexico-semantic items in narration, gendered sentences, and items such as metaphors, adjectives, and their frequency, grammar, and different lexical items such as those related to colors. Also, Short's ideas about powerful/ powerless were used to discuss the dynamic of power in the relationship between Harriet and David. Through this analysis, female ideologies of the novel were also analyzed and discussed. Feminist stylistic theories were applied to explain how Harriet's language and description represent her passivity, obedience, and dependence. This study evaluates the grammatical and lexical components of the 'female sentence' to discover that female writing is unique and different from male writing. We inferred the author's feminist style through how Harriet is described as a traditional, old-fashioned, powerless, and subordinated woman. Harriet accepts the dominance of men and persuades readers to sympathize Harriet whom everyone blames for giving birth to an abnormal child who causes too much trouble for everyone.
\end{abstract}

Article information

Received:

Keywords: feminist stylistics; metaphor; grammar; lexis

5 May 2020

Revised:

27 June 2020

Accepted:

11 July 2020

DOI: 10.24071/joll.v20i2.2586

Available at https://e-journal.usd.ac.id/index.php/JOLL/index

This work is licensed under a Creative Commons Attribution-ShareAlike 4.0 International License.

\section{Introduction}

This article is a feminist stylistic analysis or a feminist approach to stylistics, which is linked with the works of Sara Mills, Deidre Burton, Virginia Woolf, and Helene Cixous and Jacques Lacan (Ufot, 2012, p.2461). They argue that for years the characterization of women in literature and literary works and the way they are treated in the society were under the influence of the dominant male group. Feminist stylistics concentrates on the study of texts from a feminist point of view. It is defined as a sub-branch of stylistics that focuses on how gender concerns are linguistically encoded in the text. Feminist stylistics explains sexism and investigates the point of view, agency, metaphor, or transitivity to represent gender in a text. It tries to deduce the hidden and the overt sexism in a text to relate the style and content of a text with issues related to gender and to scrutinize feminine as Helen Cixous states. The difference between feminist criticism and feminist stylistics is that feminist criticism attempts to deconstruct the genders of the established roles have along with 
discourse analysis, while feminist stylistics emphasizes both discourse and the style in which the discourse is divulged.

Mills (1995) discusses the concerns related to feminist stylistics and associate it with critical linguistics, Halliday's systematic linguistics, literary stylistics, and discourse stylistics. The common points of these elements go beyond the theoretical model of linguistics and involve the factors outside the text. She asserts that for analyzing text factors such as the context, race, class, and gender should be taken into consideration and claims that analyzing a text completely in isolation is something that is not done any more or is "an outdated inheritance" (p. 5). Considering the relationship between language and social forces gives this field, like any other field, a chance to maintain a political outlook against the ideological messages embedded in a text. Not only feminist stylistics tries to interpret the texts and decipher the patriarchal discourse in both subject matter and content but also it focuses on the formation and process of discourse (Arikan, 2016; Shah et al., 2014).

This approach tends to highlight in several ways, the contrasts exist between the sexes. In early feminist stylistics, the focus was on the similarities that existed between both women and men. For a time, this idea was prevalent that there were no considerable differences in the style of women's writing with the style of men's writing and both sexes express the existence of simple and complex structures and the lexical choices nearly with the same degree. However, recently this emphasis has changed. Now, many feminist stylisticians reiterate that there is a woman's writing, which is basically and stylistically different from men's writing. Needless to mention that the discussion about whether women write in a different and significant way in comparison with men's style of writing is not a new debate. This begins by the work of Virginia Woolf who asserted that women writers have developed sentences called "the female sentences" or "the sentences of female gender" which are different from the male sentences (Mills, 1995, p. 4).
Modern feminist stylisticians claim that even the way women think and perceive reality is different from the way men do. Feminist stylisticians also refer to a technical term called genderlect, which is the linguistic differences in the way women and men understand social realities. They state that female writing considerably contrasts men in terms of its thematic concerns and formal linguistic components, and Mills describes it as "gendered sentence". The distinctions between the writing of women and men occur in lexical, grammatical, and thematic components which will be discussed more thoroughly later in this article.

Mills (1995) also emphasizes that "reality is organized along gendered lines" (p. 11), and tries to control oppressive, controlling social structures, by using political viewpoints and socioeconomic factors that permit a language to appear. On the other hand, feminist stylistics is not simply an academic exercise, yet it has a political aim by focusing on gender as a social, political, and ideological category.

In brief, the aim of feminist stylistic analysis as Mills (1995) states is to "read against the grain" (p.53). In other words, through the power of language, it tries to turn the traditional discourse upside down because she believes that the majority of western literature is about the way men described women (Mills, 1995, p. 53). Mills (2006) also believes that to evaluate the meanings or terms related to gender, analyzing different aspects of the text is not sufficient and we must consider the way readers react or process the meaning too (p. 221). Thus, reader-response theory should also be included in such an analysis.

Doris Lessing (1919- 2013) was a feminist and a post-World War I fiction writer that concerns (manifested in her writings) social problems and political changes that happened in the 20th century and World War I's aftermath, especially the events that took place in England in those days. She was also a member of the communist party. She worked on different subjects such as gender politics, mysticism, communism, racism, psychology, and psychological analysis of the human mind. As mentioned earlier, Feminist stylistics focus 
is not only on linguistics features but also on political, social, and gender issues, and choosing a writer who is both a feminist and a social activist seems helpful for this analysis.

The novel The Fifth Child (1988) is a gothic horror story about an abnormal, terrifying, goblin-like fifth child of a wealthy family called Lovatt. It tells how this boy has ruined his family's life and is gradually abandoned by his family members and later in its sequel novel Ben in the World (2000) from the society (or in a more precise term from the world). The story is narrated by a heterogenous, omniscient, and overt narrator that seems to know everything about the characters though focused on Harriet and her feeling, behavior, and action. The author acts as the vocalizer of the story. In other words, she acts like lenses through which we learn about the events and other characters of the story, specifically Ben. For example, her lack of love toward Ben as a newborn baby and calling him a monster who has ruined her happy married life or feeling pity for him or herself, or seeing herself guilty and responsible for giving birth to an animal-like and dangerous child and gives herself the right to abandon him and save her already ruined family and marital life. Nevertheless, the character of Harriet, which is the main focus of this paper, unlike those active and brave women we expect to see in novels written by women is depicted as a cruel, passive, selfish, and dependent woman. It seems that Lessing is trying to criticize this character by depicting her as a subordinate, old-fashioned, passive wife, and a cruel mother.

However, the criticism is not only against Harriet but also the cruelty and selfishness of her husband. The husband abandoned his child, put him in an unknown asylum, and considered him as an animal who has ruined his happy life and blamed Harriet for giving birth to such a child. The story also criticizes their families and relatives for depriving Ben of their love or favor or abandoning Lovatts when they need their help and support. The society and social authorities are also criticized for removing or excluding an abnormal and disabled child instead of helping him.
Among many works done on the novel, one can mention, Islam's (2013) analyzes Ben as vulnerable, unknown, marginalized other who occupies the fictional space of resistance and activism at the borderline of the society through Michel Foucault's early work on power and Zygmunt Bauman's theory on liquid. Raefipour (2012) discusses how all characters, especially Ben, complete their Kristevan's psychic cycle. On the other hand, Zhao (2012) analyzes the narratological structures of the novel: voice, person, focalization, and point of view.

None of the studies analyzed the character of Harriet through a linguistic and a feminist stylistic perspective to delve into the inner layers of her personality and character to achieve a better understanding of her actions and behavior. The gap this study tries to fill is to investigate the feminist and anti-feminist features related to Harriet's character through the feminist stylistic approach. In the other words, we try to analyze how female ideology and feminist or anti-feminist themes are expressed through the choice of the language and the narration in the story. This study attempts to depict the experiences of this married woman, the gender issues, the lexical, thematic, grammatical elements, and social factors in the story. By the help of feminist stylistics, we aim to investigate how Harriet perceives and understands the social realities. To document how gender differences are represented in the story, adjectives, and their frequency in the novel, the terms related to colors, the sentence structure, metaphor, and the sentence types (whether they are emotional or logical) will be taken into consideration.

\section{Methodology}

This paper is intended to analyze the novel The Fifth Child from the perspective of feminist stylistics. To analyze the gender issues, this study attempts to combine literary and linguistic theories by using the theory of feminist stylistics proposed by Sara Mills in 1995. The linguistic analysis includes the lexical, thematic, grammatical elements related to the character of Harriet and her passivity and dependence. By applying Mills (2005) notions we try to investigate the lexico- 
semantic items in narration, gendered sentences, and items such as metaphors, adjectives, and their frequency, grammar, and different lexical items such as those related to colors. For analyzing the deficit theory which shows the earliest stance about the characteristics of women's linguistics as being ineffective or lacking in comparison with men, Montoro (2014) will be taken into consideration. Short's theory is applied to investigate who is powerful or powerless in the novel, or who controls and who obeys.

\section{Results and Discussion}

Before analyzing the feminist stylistic features in the novel first we introduce some features which can help us in the feminist stylistic analysis:

1. In an interaction, Women are more talkative than men with longer explanations or comments. Men are distinguished as having a minor part and women as having a major part in talking (Tennen, 1990, p.36).

2. Women have more diversity in speech than men in matters such as class, race, disability, sexual orientation, and other social discriminations (Westlund, 2018, pp. 207-382).

3. Sexism or sexist sentences or statements are usually used to show the oppression of the women or the unfair, irrelevant, impertinent distinction between the two sexes (Vetterling-Braggin, 1981, pp. 2-3), it is important to consider the way these sexist statements are embodied through language, which is used either "consciously or unconsciously" (Mills, 1995, p.64) and how they may cause the alienation or the non-conductive communication of females or even males in the society.

4. Usually, lexical gaps related to sexism or gender-free terms or neutral terms are used a lot in a text or story written by a female writer. In a feminist stylistic analysis, we should consider how much patriarchal or phallocentric society is shown within the story and what are the attempts of the female writer to make it less patriarchal or unfair.
5. Based on the deficit theory, women's language is shown as ineffective, powerless, and lacking in comparison with men and they tend to us lexical hedges or fillers (e.g. you know, however, because, so, sort of, well, you see), 'empty' adjectives (e.g. divine, charming, cute), or precise color terms, such as having different names for different spectrums or shades of blue, for example blue-green, blue-violet, cornflower, cadet blue, aquamarine, navy blue, etc. (Montoro, 2014, p. 349).

6. Syntactically or grammatically women usually prefer longer sentences with a detailed description, subordination (hypotaxis; suppression; inequality) or co-ordination (parataxis; inequality) but men's sentences have the effect of suppressing, hierarchical, ordering, and controlling while women usually use antihierarchical, decentered, and non-linear sentences (Mills, 1995, p. 157).

7. Female sentences are linked, either by conjunctions such as 'however' or 'nevertheless' (which shows the speaker doesn't have the authority), or by 'but' and 'and', or the verbs used concern with action, doing, or reporting feelings, emotions. The narration should also be considered, for example, whether the narration is in first person or third person, and whether it is from a character within the text or a voice external to the text. Paying attention to the style used in the text is also important, for example considering whether the style is a scientific report, color supplement journalism or an intimate confessional autobiography or considering the voice of the author and see whether it is a female voice or not, is it intuition (and thus probably drawing on stereotype) or is there some evidence for your assumption? (Mills, 1995, p. 158)

8. Considering grammar and punctuation, for example, women, apart from their age or class in society, tend to use more standard grammar, punctuations, and pronunciations. Women use cursing or vulgar words less than men in their speech. They usually use words that show doubt or uncertainty such as 'kind of', 'somehow', 'maybe', or applying tag 
questions at the end of their sentences such as 'is it?' or 'aren't they?' which emphasizes on their uncertainty or doubt and also shows the nature of women's speech that tend to have a dual contribution in their discourse rather than men who usually dominate the discourse (Homles, 1984; Labov, 1972; Milroy, 1980).

9. Thematically, the female sentence is seen as apologetic, lacking in rationality and authority, and associated with emotions and mostly describes female experiences, while male sentences have the features of control and authority and usually are said to be clear and rational (Mills, 1995).

To reveal a systematic reading, we begin with the detailed descriptions of the characters' appearances to show how a woman may portray the appearance of another person in her writing. The examples are what somebody wears from head to toe, the color of the laces, nail polish, things on the forehead of the character, or the virginity or loss of it which are mostly related to women and their experience, such as "she was here tonight, in a scarlet dress with black lace, a witty travesty of a flamenco dress". Other examples are "it was pure nineteen-twenties, for her black hair was sleeked down into a spike on her neck at the back, with two glossy black spikes over her ears, and a black lock on her forehead" (Lessing, 1988, p. 9), or "for Harriet, she was a virgin. 'A virgin now,' her girlfriends might shriek; 'are you crazy?' "(Lessing, 1988, p. 9).

Harriet describes her virginity as a deliciously wrapped up gift ready to be given to somebody (Lessing, 1988, p. 9), talking about virginity, seeing it as a gift, or the oddness of being virgin or being mocked for that in a society which doesn't consider the loss of virginity before marriage as a taboo, is also another cultural or social feature related to the experience of women and is mostly seen in female writings. The narrator also mentions "... in a scarlet dress" (Lessing, 1988, p. 9), the color scarlet or bright red also indirectly refers to virginity (and loss of it), and somehow may remind us of Nathaniel Hathorne's novel The Scarlet Letter (1850) which deals with the loss of virginity, sin, and guilt. The use of precise colors is also an example of the deficit theory which shows the potentially discerning writing of women (Montoro, 2014, p. 349).

The traditional and old-fashioned ideas of Harriet about chastity and the importance of being virgin before marriage are shown in the following extracts, "with the chilly contempt that good women of her grandmother's generation might have used", "She is quite immoral you know", "she's no better than she ought to be", "she hasn't got a moral to her name", and "she's man-made or a nympho" (Lessing, 1988, p. 10). These examples also infer her passivity and the acceptance of the dominance, phallocentrism, and patriarchy of the men (David in this story) which will be discussed later in this study.

The other point in this feminist stylistic analysis is the number of adjectives used to describe something and the choice of different adjectives with a precise description as we can see in the following example: "he laughed. A loud, reckless, unscrupulous laugh, quite unlike modest, humorous, judicious David" (Lessing, 1988, p. 16), three adjectives (loud, reckless, unscrupulous) for a laugh and three adjectives (modest, humorous, judicious) for David were used and also the adverb 'quite' and the adjective 'unlike' adds to the exactness of description. It seems that women for their descriptions need more words and adjectives and their descriptions should be detailed and precise.

The adjectives used for the description of David and his laugh don't have positive connotations in this context, as if they are chosen critically. These words tell something about the personality and character of David as being loud, scrupulous, reckless, and not judicious, modest, or humorous anymore. As if the new condition has changed his character and made a new person out of him. Later in the novel, we see that David instead of supporting Ben or helping him, cruelly places his child, in an unknown asylum (Lessing, 1988, p. 92) and even considers him as a throwback and not his child.

In the extract, "the room was quite dark, it looked vast, like a black cave that had no end. A branch scraped across a wall somewhere 
close. There was a smell of cold rainy earth and..." (Lessing, 1988, p. 16), besides the precise and detailed description of the scene and emphasizing the gothic horror theme of the novel, the extract also gives further information. The room is described as a cold, dark and a vast cave or tunnel with no end, this description beside transferring a negative and mysterious feeling to the readers can also symbolically signify the endless, dark, terrifying, and cold relationship of the life of this married couple after the birth of their fifth child or the cold, terrifying and dark atmosphere that has dominated the whole family or the large endless gap that has occurred among Harriet and David and also children after the birth of Ben, as if that happy beautiful house has turned into a cold and dark place or the happy life of Lovatts who seem to love everything and everybody before the birth of Ben (Lovatt also seems to be a play on the word 'love it') has ruined. It seems that all their fire of love and happiness has to turn into the cold dust of indifference, hatred, and fear.

As mentioned above one of the elements used a lot in the writings of women is the precise descriptions of colors (Lakoff, 1975), for example using "grey-blue eyes" for the description of the eyes of David or using "cold dark" for the description of David's hair or "jade green" for the description of Harriet's eyes.

As mentioned before, usually women use longer and more detailed sentences in their writing (Mills, 1995, p. 158), as we can see in the following sentence from the novel:

If Harriet had seen her future in the old way, that a man would hand her the keys of her kingdom, and there she would find everything her nature demanded, and this as her birthright, which she had - at first unknowingly, but then very determinedly been traveling towards, refusing all muddles and dramas, then he saw his future as something he must aim for and protect. (Lessing, 1988, p. 13)

By a long sentence, we mean a sentence with many words in it which are connected, with no full stop (as we can see in this extract). Usually writing a long sentence allows the writer to use more words for a more precise, detailed, careful, and exact description and also slows down the description and creates a sense of time dragging and relaxation and the chance to imagine the scene better. Usually, we hear that women in their speaking use long sentences with details and descriptions as if they need more words to elaborate on something.

Grammatically, women's sentences tend to be complex both grammatically, by being grammatically complex (complex sentences) we mean the sentences are consisted of one independent clause and at least one dependent clause or subordinated clause (as mentioned before, subordination shows hypotaxis, suppression, and inequality and co-ordination also show inequality and parataxis) which are connected by subordinating conjunctions such as 'after', 'as if', 'if', 'then', 'because', 'that', 'while', 'where', etc. This extract consists of one independent clause ("she would find everything her nature demanded") and several dependent clauses ("if Harriet had seen her future in the old way", "that a man would hand her the keys", " then very determinedly - been traveling towards") and its independent clauses are marked by subordinating conjunctions (if, then, that, which), needless to mention that this extract also consists of coordinate sentences which are connected by "and", but the complex sentences were dominant and shows the character's suppression.

Thematically, the above-mentioned extract also seems to be an example of a sexist statement in which Harriet was depicted as an ineffective and passive woman who is waiting for a man to come and gives her the keys of the kingdom of happiness, as if she can't achieve it herself and needs someone else's help, also the female character of the novel is depicted as more irrational and dreamy and less logical.

Mills (1995) claims that in feminist stylistic analysis the schemata or the previous or background knowledge of a person is more important than the sentence structure (p.59), this means that Lessing had some background knowledge about Ben, for example, in the first interview about this novel she said that her inspiration for writing this novel originates from her interest in little people, goblins, and 
changelings; the second one from her reading of an archeologist who was astonished to encounter a Neanderthal girl in Maine and the last one from a letter to the newspaper editor that she read someday in which a woman anxiously declared that her fourth child has ruined the happiness of the family (Lessing, 1988, p.1). The third interview which is the main background knowledge used by Lessing is closely related to this novel and Harriet as a helpless woman who sees her fifth child as someone who has ruined her happy life. According to this claim, regarding the schemata theory, we should pay attention to the schemata more than the sentence structure because the rules related to sentences are not true in all cases, for example, Leonardi (1986) believes that women use coordinate clauses more than subordinate clauses to reject the dominance of men through sentences (p. 151) while Mills (1995) believes women use subordinate clauses more for its complexity.

There are other assumptions about female sentences which infer that women talk about emotion and feelings in their writing more than logic and their writings are not rational or clear as men's writing or their writing is based on their experiences, but these assumptions are not completely dependable or true because, for example, a man by knowing the conventions of écriture féminine can write a woman's book (Mills, 1995, pp. 39-40). This means that writing as a female or a male writer is not restricted to gender, for example, a man can write like a female and vice versa.

As it was mentioned, women's writing is more emotional and less logical. An example from the novel which can help us, in this case, is the part David puts Ben in an asylum for extraordinary and abnormal people, but Harriet, despite her hatred and fear toward Ben, gets emotional and instinctual like a mother. She can't tolerate her son's suffering and pain so she drives to that place, finds Ben in a bad condition ("covered with his excrement"), feels pity for him and takes him home (and blames herself for what she had done the rest of the story) (Lessing, 1988, p.9293).
The most common notion about female writing is the use of metaphors (Mills, 1995, pp. 39-40), as you can see in this extract, "With his yellowish stubbly low-growing hair, his stony unblinking eyes, his stoop, his feet planted apart and his knees bent, his clenched held-forward, he seemed more than ever like a gnome" (Lessing, 1988, p. 89). For example, in a metaphor like "his stony unblinking eyes," the narrator tries to show that his eyes are fixed somewhere as if they are like stones, static, fixed, unmoved, and cold. Or "his feet planted" is another example of metaphor to show that Ben doesn't move at all, like a tree planted on the ground. The other feature is the precise color description like "yellowish stubby low-growing hair" and too many details used in the description of the character (which we discussed previously).

\section{Who is the Powerful/ Powerless Speaker?}

Perceptions of power and domination are related to the perceptions or attributes of control. If this person is recognized as strong, she or he is seen as having control over people, resources, and self but the important question is how language or stylistic features can show such perceptions or attributes of control. Short (1996) suggests several questions to identify the powerful and powerless speakers in verbal interaction. Short's criteria of questions deal with the natural characteristics of dialogues or conversations, such as topic control, interruptions, etc. which may help to gain insights into differences in communication between the male and female characters in the novel.

Powerful speakers in a conversation have the most turns, show the exchanges of the conversation, control what to talk about, and when to talk about it, and who interrupts the other. An analyst may notice that the number of turns can be considered only in the case of more than two speakers (i.e. more than two characters); two-character conversations follow exactly this general pattern. Each rule has expectations/ variations. For instance, in an interview "the least powerful person, the interviewer, will be expected to take the longest turns precisely because the purpose of 
the interview is to judge the candidate based on what he or she says" (Short, 1996, p.207).

Short (1996) identifies the powerful and the powerless speakers in the conversations which are through applying the questions in the list below to the characters' speeches. In Short's Exploring the Language of Poems, Plays, and Prose the application of these questions is applied to the dialogues of Shakespeare's Richard III between King
Richard and the Duke of Buckingham, in fighting out the powerful had the powerless speech of two male characters. In Lessing's The Fifth Child, we want to see that in the subtle distribution of power between Harriet and David, which side has power when interacting with the other (p.206). The table below is Short's model of identifying powerful/ powerless in speech.

Table1. Short's model of identifying powerful/ powerless in speech

\begin{tabular}{|l|c|c|}
\hline & Powerless speaker & Powerful speaker \\
\hline Who has more turn? & & $\mathbf{x}$ \\
\hline Who has the least? & $\mathbf{x}$ & $\mathbf{x}$ \\
\hline Who has the longest turn? & $\mathbf{x}$ & $\mathbf{x}$ \\
\hline Who has the shortest? & & $\mathbf{x}$ \\
\hline Who initiates conversational exchange? & $\mathbf{x}$ & $\mathbf{x}$ \\
\hline Who responds? & & $\mathbf{x}$ \\
\hline Who controls the conversational topic? & $\mathbf{x}$ & \\
\hline Who follows the topic of others? & & $\mathbf{2}$ \\
\hline Who interrupts? & $\mathbf{x}$ & \\
\hline Who is interrupted? & & \\
\hline $\begin{array}{l}\text { Who uses the terms of address not marked } \\
\text { for respect (e.g.first name only)? }\end{array}$ & & \\
\hline $\begin{array}{l}\text { Who uses terms of address marked for } \\
\text { respect (e.g.title+ last name)? }\end{array}$ & & \\
\hline
\end{tabular}

To analyze the powerful and the powerless in this novel, we have chosen an extract from Harriet and David's conversation in the novel:

It will all be easier when Christmas starts,' wept Harriet.

'You can't be serious,' said David, furious. 'Of course, they can't come this Christmas.' 'But it is so easy when people are here, everyone helps me.'

'Just for once we'll go to one of them,' said David, but this idea did not live for more than five minutes: none of the other households could accommodate six extra people. Harriet lay weeping on her bed. 'But they must come, don't put them off - oh, David, please ... at least it'll keep my mind off it.' He sat on his side of the bed watching her, uneasy, critical, trying not to be. (Lessing, 2000, p.22)

It seems they both have equal turns (three turns), David's speech contains shorter sentences but more direct, logical, and exact than Harriet's, but on the other hand, Harriet has longer sentences with pauses (put them off -), gaps (please ...) and sentence fillers (oh), and seems more emotional. The one who initiates the conversation is Harriet and the one who responds is David, the one who interrupts is Harriet when she says "But it is so easy when people are here, everyone helps me." And the one who is interrupted is David, and also the one who used the first name in this conversation is Harriet, based on this brief analysis, it seems that in this interaction based on Short's categorization in the table above the 
powerful is Harriet and the powerless is David but, it is vice versa, David is not necessarily a powerless character, he speaks with determination and dominancy, for example, he doesn't want their relatives to come to their house due to the reasons he mentions, he uses his anger ("said David, furious") to show his power and force Harriet to obey him, while on the other side, Harriet tries to change his opinion but she is not successful.

Short (1996) claims that two-character conversations may have the equal number of turns; however not all the conversations follow exactly this general pattern, so although based on the above classification, Harriet seems powerful but in fact, David is the powerful one because he is the one who controls the conversation or decides, this adds to our previous discussion about Harriet, that she is the one who is dominated and David is the one who dominates everything and makes the decision. Even later in the story, David decides to put Ben in an asylum without telling Harriet about it (Lessing, 1988, p. 92).

In other parts of the story we can also see the dominance of David and the powerlessness of Harriet, for example, is a part of the novel when they were together in their bedroom and although they had decided to postpone having any child for the next two years, she is overwhelmed by David's purpose and lust and they make love together, as the narrator says, "he was making love with a deliberate, concentrated intensity, looking into her eyes, that made her accept him, his taking possession of the future in her" (Lessing, 1988, p. 15), while, both of them mistrusted prevention bills for preventing the pregnancy which results in Harriet pregnancy (which adds to their traditional mindset). This pregnancy and avoiding to take the bills for preventing it beside David's dominance in the decision about having any children despite their agreement of not having a child in the next two years and the previous descriptions and information about Harriet strengthen this idea that we are dealing with an old-fashioned woman with traditional believes who probably has no problem with men's dominance or patriarchy, even their choice of the house at the beginning of the novel, foreshadows the patriarchy presented in the novel, "a large
Victorian house in an overgrown garden" (Lessing, 1988, p. 13), choosing a Victorian house signifies something old (i.e. oldfashioned), in other words, it transfers to the readers that they are reading about a large old house with people who also have traditional and old-fashioned ideas, it also transfers the feeling of being in a patriarchal society in which the man is the one who decides and this somehow reminds us of the couples themselves.

The Victorian house and its overgrown garden explicitly refer to the fertility and the decision of Harriet and David about having lots of children in this house like Victorian families (Victorian families were usually large families with lots of children), they refer to this tendency in extracts like, " . . they 'would not mind' a lot of children. 'Even four, or five...' 'Or six,' said David. 'Or six!' said Harriet" (Lessing, 1988, p. 13), or "And how many kids are you planning, if one may?... 'A lot,' said David ... 'A lot,' said Harriet" (Lessing, 1988, p. 20)

\section{Conclusion}

The aim of this study we discussed the feminist stylistic features such as lexical, thematical, and grammatical elements used by a female writer to see how she depicts her female character within the novel. Feminist stylistics was applied to discuss how Harriet's language and descriptions show her passivity, obedience, and dependence. This study proved that feminity had been subordinated in Harriet's part and she is a powerless character. To achieve the main goal of this research, Mills' and other feminist stylisticians theories and Short's model of power relations were applied in the analysis which helped us to prove these features about Harriet. Based on what we discussed and analyzed, it can be inferred that the style of the writer in this novel is a feminist style through which either the writer tries to criticize the character as a traditional, oldfashioned, subordinated woman who has no problem with the dominance of men or wants the reader to sympathize with Harriet whom everyone blames for giving birth to an abnormal child who causes too much trouble and suffering for everyone. 


\section{References}

Angelova, N. (2014). Data Pruning (Master's Arikan, S. (2017). Angela Carter's the Bloody Chamber: A feminist stylistic approach. Furat Üniversitesi Sosyal Bilimler Dergisi, 26(2), 117-130.

Hiatt, M. (1977). The way women write. New York: Teachers' College Press.

Holmes, J. (1984). Hedging your bets and sitting on the fence: Some evidence for hedges as support structures. Te Reo, 27(1), 47-62.

Islam, M. S. (2013). Anticipating apocalypse: Power structures and the periphery in Doris Lessing's The Fifth Child and Ben, in the World. Romanian Journal of English Studies, 10(1), 278-29.

Labov, W. (1972). Language in the inner city: Studies in the Black English vernacular. Philadelphia, PA: University of Pennsylvania Press.

Lakoff, R. T. (1975). Language and women's place. New York: Harper Colophon Books.

Lessing, D. (2010). The fifth child. New York: Vintage.

Leonardi, S. J. (1986). Bare places and ancient blemishes: Virginia Woolf's search for a new language in Night and Day. Novel: $A$ Forum on Fiction, 19(2), 150-163.

Milroy, L. (1987). Language and social networks. Oxford: Blackwell.

Mills, S. (1995). Feminist stylistics. London: Routledge.

Montoro, R. (2014). Feminist stylistics. In M. Burke (Ed.), The Routledge Handbook of Stylistics, 326-361. Oxon: Routledge.

Raefipour, N. (2012). Ben, a stranger in the dark society of mirrors. Epiphany, 5(1), 71-82.

Shah, S. K., Zahid, S., Shakir, A., \& Rafique, S. (2014). Representation of women in Mann O Salwa: A case study through feminist stylistic analysis. Research on humanities and social sciences, 4(7), 90105.

Tannen, D. (1991). You just don't understand: Women and men in conversation. London: Virago.

Trudgill, P. (1972). Sex, covert prestige and linguistic change in the urban British English of Norwich. Language in society, 1(2), 179-195.

Ufot, B. G. (2012). Feminist stylistics: A lexicogrammatical study of the female sentence in Austen's Pride and Prejudice and Hume-Sotomi's The General's Wife. Theory and Practice in Language Studies, 2(12), 2460.

Vetterling-Braggin, M. (1981). Sexist language: A modern philosophical analysis. Totowa: Littlefield Adams.

Westlund, A. C. (2018). Relational autonomy and practical authority. In T. A. Van Dijk (Ed.), Handbook of Discourse Analysis, 4, 103-124. London: Academic Press.

Zhao, K. (2012). A narrative analysis of Lessing's The Fifth Child. Theory \& Practice in Language Studies, 2(7), 14981502. 